\title{
Wykorzystanie metodyk zarządzania projektami w świetle badań empirycznych
}

Dr Maciej Brzozowski

Uniwersytet Ekonomiczny w Poznaniu, Instytut Zarządzania Katedra Zarządzania Strategicznego

\section{Wprowadzenie}

Zarządzanie projektami jako obszar wiedzy rozwinęło się przede wszystkim w odpowiedzi na potrzeby praktyki gospodarczej, której istotnym elementem stały się powszechnie występujące, niepowtarzalne przedsięwzięcia ${ }^{1}$. Zaledwie kilka ostatnich dekad wystarczyło, aby zarządzanie projektami przekształciło się ze zbioru prostych reguł i narzędzi w kompleksową i wieloaspektową subdyscyplinę nauk o zarządzaniu, z własnym zakresem badań, podejściami badawczy$\mathrm{mi}$, terminologią oraz podstawami teoretycznymi i metodycznymi². Namacalnym efektem tego rozwoju jest bogactwo metodycznego wsparcia zarządzania projektami w postaci licznych metodyk, standardów oraz technik. Wielość metodyk z jednej strony ułatwia dobranie odpowiednich instrumentów do specyfiki projektów, z drugiej wymaga jednak dużej świadomości kadry kierowniczej i dobrej orientacji w szerokim spektrum proponowanych rozwiązań ${ }^{3}$. Zasadne wydaje się zatem pytanie: „W jakim stopniu osoby zaangażowane w projekty korzystają z dostępnych metodyk zarządzania projektami?".

Podstawowym celem artykułu jest zbadanie, na podstawie badań empirycznych, postrzeganego sposobu zarządzania projektami w organizacjach, jak również określenie częstotliwości stosowania wybranych metodyk zarządzania projektami wraz

1 E. Bukłaha, M. Juchniewicz, Kluczowe wyzwania i bariery oraz trendy w zarządzaniu projektami z punktu widzenia projektów realizowanych w Polsce, „Przegląd Organizacji” 2019, nr 3 , s. 15.

2 M. Trocki, Podejścia badawcze w zarzq̨dzaniu projektami - geneza i ewolucja, „Przegląd Organizacji” 2019, nr 3, s. 3; J.M. Lichtarski, M. Wąsowicz, Zarządzanie projektami - stan i perspektywy rozwoju subdyscypliny, [w:] K. Jędralska, W. Dyduch (red.), Nauki o zarzq̨dzaniu: dokonania, trendy, wyzwania, Wydawnictwo Uniwersytetu Ekonomicznego w Katowicach, Katowice 2017, s. 124.

3 M. Trocki (red.), Metodyki istandardy zarządzania projektami, Polskie Wydawnictwo Ekonomiczne, Warszawa 2017, s. 13. 
z oceną ich przydatności. Realizacja tak postawionego celu została przeprowadzona przez dokonanie krytycznego przeglądu (eksploracji) dorobku piśmienniczego dotyczącego metodyk zarządzania projektami, jak również przez identyfikację, klasyfikację oraz eksplikację badanych zjawisk, a następnie ich empiryczną weryfikację na grupie pracowników polskich przedsiębiorstw, zaangażowanych zawodowo w realizację projektów.

\section{Metodyki zarządzania projektami w świetle literatury przedmiotu}

Metodyki zarządzania projektami można zdefiniować jako zbiory instrumentów zarządzania oferujące zalecenia odnoszące się do całego procesu realizacji projektów, wyznaczające tok postępowania, który prowadzi do skutecznej realizacji projektu 4 . Metodyki zarządzania projektami oferują uporządkowaną wiedzę, która została uznana przed środowisko naukowców i/lub praktyków za rekomendowany wzorzec postępowania. Kluczowym elementem metodyk są procedury systemu zarządzania, które powinny podlegać ciągłemu doskonaleniu 5 .

W zależności od obszaru ich zastosowania można wyróżnić następujące grupy metodyk zarządzania projektami6:

- uniwersalne metodyki zarządzania projektami - oferujące najszerszy zakres wykorzystania w różnorodnych obszarach i sytuacjach zarządzania projektami, przygotowane najczęściej jako standardy przez organizacje zajmujące się tworzeniem i popularyzacją wzorców zarządzania projektami;

- branżowe metodyki zarządzania projektami - opracowane przez instytucje profesjonalne określonych branż i dostosowane do specyfiki projektów realizowanych w danym sektorze gospodarki;

- problemowe metodyki zarządzania projektami - odnoszące się do wyodrębnionych problemowo (np. dotyczących ryzyka projektu lub kompetencji uczestników projektu) kompleksów zadań zarządzania projektami;

- firmowe metodyki zarządzania projektami - wypracowane (często jako adaptacja metodyk uniwersalnych i/lub branżowych) oraz wykorzystywane przez duże organizacje, posiadające bogate doświadczenia w realizacji projektów;

4 A. Szpitter, Metodyki zarzq̨dzania projektami stosowane przez project managerów u operatorów systemu dystrybucyjnego w Polsce. Studium empiryczne, Wydawnictwo Uniwersytetu Gdańskiego, Gdańsk 2018, s. 16.

5 E. Głodziński, Efektywność w zarzq̨dzaniu projektami, Polskie Wydawnictwo Ekonomiczne, Warszawa 2017, s. 176.

6 M. Trocki (red.), Metodyki i standardy..., s. 28-34. 
- autorskie metodyki zarządzania projektami - publikowane w formie podręczników i monografii, a stanowiące syntezę wiedzy i profesjonalnych doświadczeń ich autorów.

Dobór i dostosowanie odpowiedniej metodyki zarządzania projektami do specyfiki danej organizacji i jej aktywności projektowej jest złożonym zagadnieniem, ściśle powiązanym $\mathrm{z}$ jednej strony $\mathrm{z}$ atrybutami poszczególnych metodyk, a z drugiej zależnym od uwarunkowań samych organizacji oraz indywidualnych preferencji osób zaangażowanych w realizację projektów ${ }^{7}$.

Przedmiotem niniejszego opracowania są wybrane uniwersalne metodyki zarządzania projektami. Do najpopularniejszych przykładów tego rodzaju metodyk zaliczono następujące: PMBoK (Project Management Body of Knowledge), PRINCE2 (Projects in Controlled Environments), IPMA (International Project Management Association), TenStep (TenStep Project Management Process), metodyki zwinne (w szczególności Scrum) ${ }^{8}$.

PMBoK został opracowany jako standard zarządzania projektami przez Project Management Institute (PMI) w Stanach Zjednoczonych. Metodyka PMBoK jest zbiorem najlepszych praktyk mających zastosowanie w zarządzaniu projektami. Zostały one pogrupowane w 47 procesów, którym towarzyszy odpowiedni zestaw: informacji zasilających proces, dokumentów inicjujących proces, technik pomocnych w realizacji procesu oraz rezultatów procesu. Procesy w metodyce PMBoK zostały pogrupowane w układzie dwuwymiarowym. W pierwszym wymiarze wskazano dziesięć obszarów wiedzy: zarządzanie zakresem w projekcie, zarządzanie czasem w projekcie, zarządzanie kosztami w projekcie, zarządzanie jakością $\mathrm{w}$ projekcie, zarządzanie zasobami ludzkimi w projekcie, zarządzanie komunikacją w projekcie, zarządzanie ryzykiem w projekcie, zarządzanie zamówieniami w projekcie, zarządzanie zaangażowaniem interesariuszy w projekcie, zarządzanie integracją projektu. W drugim wymiarze grupowania procesów wykorzystano ideę cyklu życia projektów dla wyodrębnienia następujących grup procesów zarządzania projektami: grupa procesów inicjowania, grupa procesów planowania, grupa procesów realizacji, grupa procesów monitorowania i kontroli, grupa procesów zamknięcia9.

7 B. Nogalski, A. Szpitter, M. Jabłoński, Zarzq̨dzanie projektami w kształtowaniu elastycznych modeli biznesu operatorów systemu dystrybucyjnego, Wydawnictwo Uniwersytetu Gdańskiego, Gdańsk 2016, s. 24.

8 Przekrojową oraz kompleksową charakterystykę metodyk i standardów zarządzania projektami zawiera pozycja M. Torcki (red.), Metodyki i standardy...

9 A Guide to the Project Management Body of Knowledge, Fifth edition, Project Management Institute, Inc., Management Training and Development Centre, Warszawa 2013. 
Drugą najpopularniejszą - obok PMBoK - metodyką zarządzania projektami jest metodyka PRINCE2 wywodząca się z Wielkiej Brytanii i opracowana przez Office of Government Commerce. Struktura tej metodyki opiera się na trzech zintegrowanych składowych: pryncypiach, tematach oraz procesach. Do kategorii pryncypiów zaliczono: ciągłą zasadność biznesową, korzystanie z doświadczeń, zdefiniowane role i obowiązki, zarządzanie etapowe, zarządzanie z wykorzystaniem tolerancji, koncentrację na produktach, dopasowanie do środowiska projektowego. Tematy opisane w metodyce PRINCE2 to: uzasadnienie biznesowe, organizacja, jakość, plany, ryzyko, zmiana, postępy. Realizacja projektu w metodyce PRINCE2 angażuje siedem procesów uporządkowanych od kontrolowanego startu aż do oczekiwanego zakończenia. Są to następujące procesy: przygotowanie projektu, strategiczne zarządzanie projektem, inicjowanie projektu, sterowanie etapem, zarządzanie dostarczaniem produktów, zarządzanie końcem etapu, zamykanie projektu ${ }^{10}$.

Metodyka IMPA opracowana została przez International Project Management Association - międzynarodową federację stowarzyszeń popularyzujących i certyfikujących wiedzę z zakresu zarządzania projektami. Metodyka ta opiera się na podstawowym założeniu, że o skuteczności i efektywności zarządzania projektami decydują przede wszystkim kompetencje osób uczestniczących w projekcie, natomiast mniejsza jest waga procesów. Model kompetencji IPMA (IPMA Individual Competence Baseline - ICB4) obejmuje 29 kompetencji podzielonych na trzy grupy: kompetencji technicznych (obszar „Praktyka”), kompetencji behawioralnych (obszar „Ludzie”) oraz kompetencji kontekstowych (obszar „Perspektywa”)11.

Metodyka TenStep została opracowana przez Toma Mochala dla koncernu Coca-Cola. Bazuje ona na dobrych praktykach opisanych w metodyce PMBoK oraz przyjmuje założenie o istotnym wpływie skali projektu na poziom złożoności procesów oraz czas i precyzję zarządzania projektem. Struktura procesów metodyki TenStep obejmuje następujące kroki ${ }^{12}$ :

- definiowanie przedmiotu dostawy,

- tworzenie harmonogramu i budżetu,

- zarządzanie harmonogramem i budżetem,

- zarządzanie problemami krytycznymi,

- zarządzanie zakresem,

10 OGC, Managing Successful Projects with PRINCE2, The Stationery Office, London 2009.

11 IPMA, Wytyczne Kompetencji Indywidualnych w Zarzqdzaniu Projektami, Programami i Portfelami. IPMA Individual Competence Baseline ${ }^{\circledR}$ (IPMA ICB). Wersja 4.0, 2015; M. Brzozowski, P. Bartkowiak, Kompetencje uczestników projektu w świetle badań empirycznych, „Przegląd Organizacji” 2019, nr 8, s. 42.

12 TenStep Project Management Process v13.0, June 2014. 
- zarządzanie komunikacją,

- zarządzanie ryzykiem,

- zarządzanie zasobami ludzkimi,

- zarządzanie jakością i miarami,

- zarządzanie zamówieniami.

Opisane powyżej metodyki zalicza się do tradycyjnego podejścia do zarządzania projektami, którego istota sprowadza się do koncentracji na działaniach związanych z planowaniem etapów projektu i osiąganiem celów zgodnych z oczekiwaniami klientów ${ }^{13}$. Odmienne podejście oferują tzw. zwinne metodyki zarządzania projektami, będące odpowiedzią na zmieniające się warunki funkcjonowania współczesnych przedsiębiorstw, a w szczególności postęp technologiczny (w tym technologii informacyjnych), narastającą dynamikę zmian otoczenia oraz globalizację. Zwinne podejście do zarządzania projektami jest zorientowane na to, aby projekt mógł posłużyć do wytworzenia innowacyjnego produktu w warunkach niepewności wynikającej z niedookreślonych końcowych właściwości wytwarzanego produktu oraz braku ustalonych sposobów jego wytworzenia. Podejście to nie koncentruje się na technikach i procesach (jak ma to miejsce w metodykach tradycyjnych), lecz na relacjach międzyludzkich, spekulatywnym planowaniu, ciągłym dostarczaniu wartości dla klienta, wiarygodnych pomiarach postępu prac na podstawie wypracowanych elementów funkcjonalności ${ }^{14}$. Grupa zwinnych metodyk zarządzania projektami obejmuje liczne propozycje, spośród których za najbardziej rozpoznawalną uchodzi metodyka Scrum. Wyznacza ona ramy postępowania, umożliwiające rozwiązywanie złożonych problemów adaptacyjnych w kreatywny sposób, który zaowocuje wytworzeniem produktów o możliwie najwyższej wartości ${ }^{15}$. Kluczowe zagadnienia metodyki Scrum to: zespoły, role, zdarzenia, artefakty oraz reguły.

\section{Metoda i próba badawcza}

Aby osiągnąć wyznaczony cel badawczy, zidentyfikowano trzy obszary badań empirycznych:

- określenie postrzeganego sposobu zarządzania projektami w organizacji,

- identyfikacja rodzajów stosowanych metodyk zarządzania projektami,

- ocena przydatności stosowanych metodyk zarządzania projektami.

13 A. Szpitter, Metodyki zarzq̨dzania projektami..., s. 26.

14 M. Brzozowski, T. Kopczyński, Zarządzanie projektami i zmianami w przedsiębiorstwie, Advertiva, Poznań 2011, s. 59.

15 K. Schwaber, J. Sutherland, Scrum Guide. Przewodnik po Scrumie: reguty gry, Scrum.Org and Scrumlnc., 2013, s. 3. 
Pomiar badanych zjawisk został przeprowadzony z uwzględnieniem następujących różnic: pełnionej funkcji w organizacji, stażu pracy respondentów oraz sektora funkcjonowania ich organizacji. Źródłem oceny są wyniki badań empirycznych zrealizowanych z wykorzystaniem kwestionariusza ankiety w latach 2016-2018 ${ }^{16}$. Zakres badań empirycznych obejmował osoby deklarujące zawodowe zaangażowanie w projekty (podmiotowy), uwarunkowania związane z zarządzaniem projektami w organizacjach (przedmiotowy), województwo wielkopolskie (przestrzenny) oraz lata 2016-2018 (czasowy). Wielkość próby badawczej wyniosła 384 obserwacje, natomiast dobór próby miał charakter celowy - kryterium doboru była deklaracja respondenta dotycząca pracy zawodowej w projektach. Struktura próby badawczej zaprezentowana została na rysunku 1.

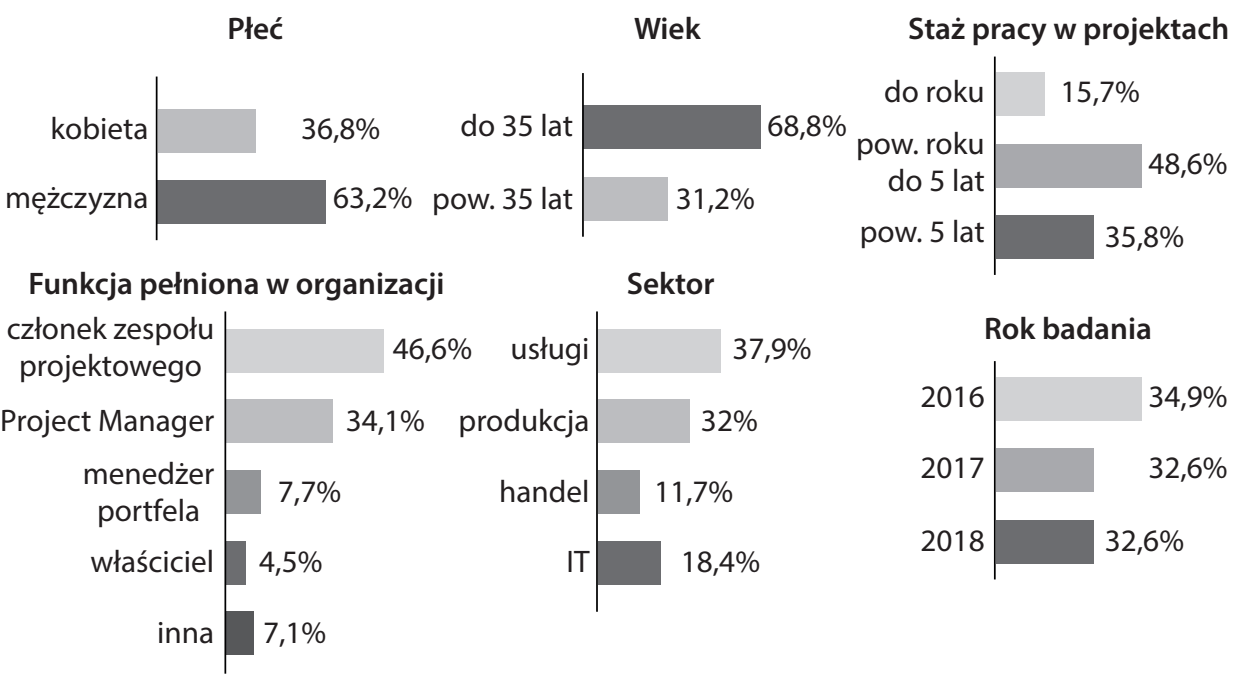

Rysunek 1. Struktura próby badawczej

Źródto: opracowanie własne.

\section{Wyniki badań}

Pierwszym obszarem postępowania badawczego jest określenie postrzeganego sposobu zarządzania projektami w organizacji.

Wyniki zaprezentowane na rysunku 2 pozwalają na szeregowanie sposobów zarządzania projektami w badanych organizacjach według częstości ich stosowania.

16 Analiza uzyskanych wyników przeprowadzona została przy wykorzystaniu programu IBM Statistics ver. 21. 
Zgodnie z deklaracjami respondentów najczęściej stosowany jest częściowo metodyczny sposób zarządzania projektami (35,2\% wskazań ogółem). Należy zwrócić uwagę, że częstość stosowania tego sposobu zarządzania projektami rośnie od niecałych 31\% w 2016 roku do ponad 38\% w 2018 roku. W dalszej kolejności wskazany został metodyczny, ale zróżnicowany sposób zarządzania projektami $(24,7 \%$ wskazań ogółem) oraz sposób przypadkowy (23,4\% wskazań ogółem). Jako najmniej popularny wskazany został kompleksowy sposób zarządzania projektami w organizacji (16,7\% wskazań ogółem).

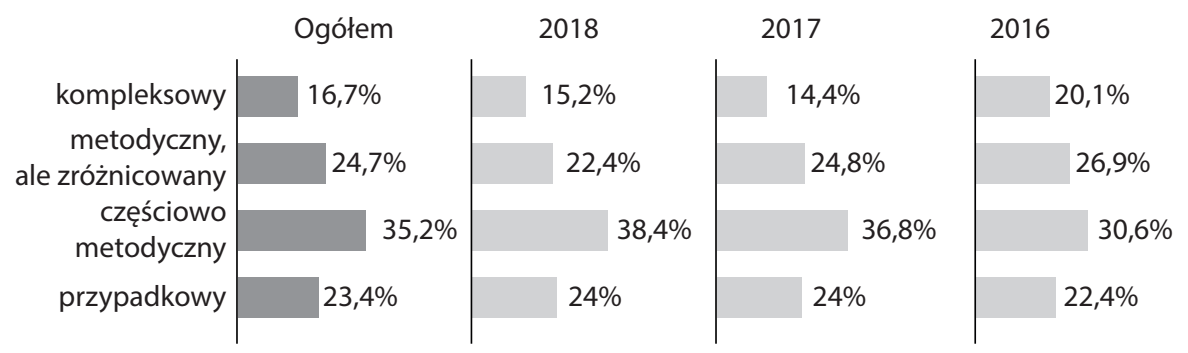

Rysunek 2. Sposób zarządzania projektami w organizacji

Źródto: opracowanie własne.

Istotnym czynnikiem różnicującym częstość stosowania badanych sposobów zarządzania projektami w organizacji jest staż pracy w projektach. Analiza uzyskanych wyników pozwala na zaobserwowanie prawidłowości, zgodnie z którą rosnący staż pracy w projektach wiąże się ze stosowaniem bardziej zaawansowanych sposobów zarządzania projektami - w przypadku respondentów z najkrótszym stażem w projektach (do roku) przeważa przypadkowy sposób zarządzania projektami (35\% wskazań). W dalszej kolejności wskazane zostały sposoby: częściowo metodyczny (28,3\% wskazań), metodyczny, ale zróżnicowany (21,7\% wskazań) oraz kompleksowy (15\% wskazań). Z kolei w przypadku osób z najdłuższym stażem pracy w projektach częstość stosowania przypadkowego sposobu zarządzania projektami jest najmniejsza (16,8\% wskazań), rośnie natomiast częstość stosowania pozostałych sposobów zarządzania projektami - na kompleksowy wskazało 24\% respondentów, na metodyczny, ale zróżnicowany ponad 26\% respondentów, natomiast na częściowo metodyczny niecałe 33\% respondentów (por. tabela 1). Uzyskane wyniki wskazują jednoznacznie na świadomość projektową rosnącą wraz ze stażem pracy w projektach, co związane jest przede wszystkim z praktyką zawodową oraz pragmatyką stosowania różnych metod i metodyk zarządzania projektami. 
Tabela 1. Sposoby zarządzania projektami w organizacji ze względu na staż pracy w projektach

\begin{tabular}{|l|c|c|c|}
\hline \multicolumn{1}{|c|}{ Sposoby zarządzania projektami w organizacji } & Do roku & $\begin{array}{c}\text { Powyżej } \\
\text { roku do 5 lat }\end{array}$ & $\begin{array}{c}\text { Powyżej } \\
5 \text { lat }\end{array}$ \\
\hline Przypadkowy (brak stosowania metodyki) & $35,0 \%$ & $24,2 \%$ & $16,8 \%$ \\
\hline $\begin{array}{l}\text { Częściowo metodyczny (są wykorzystane elementy } \\
\text { metodyki zarządzania projektami) }\end{array}$ & $28,3 \%$ & $39,2 \%$ & $32,8 \%$ \\
\hline $\begin{array}{l}\text { Metodyczny, ale zróżnicowany (poszczególne projekty } \\
\text { są zarządzane w sposób uporządkowany, zgodny } \\
\text { z metodyką, jednakże stosowane metodyki różnią się } \\
\text { dla poszczególnych projektów) }\end{array}$ & $21,7 \%$ & $24,7 \%$ & $26,3 \%$ \\
\hline $\begin{array}{l}\text { Kompleksowy (wspólna metodyka dla większości } \\
\text { realizowanych projektów) }\end{array}$ & $15,0 \%$ & $11,8 \%$ & $24,1 \%$ \\
\hline
\end{tabular}

Źródło: opracowanie własne.

Ciekawych prawidłowości dostarcza również analiza częstości stosowania wyodrębnionych sposobów zarządzania projektami ze względu na funkcję pełnioną przez respondentów w organizacji (tabela 2). Analiza uzyskanych wyników wskazuje jednoznacznie na występowanie prawidłowości, zgodnie z którą osoby formalnie odpowiedzialne za zarządzanie projektami w organizacji zdecydowanie częściej wykorzystują w tym zakresie podejście metodyczne w porównaniu do pozostałych grup badanych respondentów - w grupie project managerów najczęściej wykorzystywany jest sposób częściowo metodyczny z użyciem wybranych elementów metodyki zarządzania projektami (blisko 49\% wskazań), natomiast w grupie menedżerów portfela zróżnicowany sposób metodyczny, uwzględniający stosowanie adekwatnych metodyk zarządzania projektami w zależności od specyfiki postępowania projektowego (blisko $45 \%$ wskazań). W przypadku członków zespołu projektowego na uwagę zwraca dość częsty brak stosowania metodyki zarządzania projektami (blisko $28 \%$ wskazań) - na porównywalnym poziomie oceniono częstość występowania metodycznego, zróżnicowanego sposobu zarządzania projektami (niecałe 30\% wskazań) oraz sposobu częściowo metodycznego (ponad 31\% wskazań). Z kolei w przypadku właścicieli organizacji sposobem najbardziej popularnym jest stosowanie podejścia częściowo metodycznego (blisko 53\% wskazań), przy czym zwrócić należy również uwagę na stosunkowo częste niestosowanie żadnej metodyki zarządzania projektami (ponad 35\% wskazań).

Różnice w badanym obszarze zaobserwować można również ze względu na sektor działalności badanych organizacji (tabela 3). Analiza uzyskanych wyników wskazuje jednoznacznie na sektor IT jako ten, w którym wykorzystanie metodyk zarządzania projektami w organizacji występuje najczęściej - ponad $27 \%$ respondentów zadeklarowało stosowanie podejścia kompleksowego, ponad 30\% zróżnicowanego podejścia metodycznego, natomiast niecałe $41 \%$ podejścia częściowo 
metodycznego. Oznacza to, że jedynie w nieco ponad $1 \%$ badanych organizacji z sektora IT respondenci zadeklarowali niestosowanie żadnej metodyki zarządzania projektami. Do sektorów, w przypadku których stosowanie metodycznych sposobów zarządzania projektami występuje najrzadziej, zaliczają się handel oraz usługi (odpowiednio ponad 36\% oraz ponad 32\% wskazań dla przypadkowego sposobu zarządzania projektami). Z kolei w sektorze produkcyjnym częstość stosowania metodycznych sposobów zarządzania projektami ocenić należy jako średnią.

Tabela 2. Sposoby zarządzania projektami w organizacji ze względu na petnioną w organizacji funkcję

\begin{tabular}{|l|c|c|c|c|}
\hline \multicolumn{1}{|c|}{$\begin{array}{c}\text { Sposoby zarządzania projektami } \\
\text { w organizacji }\end{array}$} & $\begin{array}{c}\text { Cztonek zespołu } \\
\text { projektowego }\end{array}$ & $\begin{array}{c}\text { Project } \\
\text { manager }\end{array}$ & $\begin{array}{c}\text { Menedżer } \\
\text { portfela }\end{array}$ & $\begin{array}{c}\text { Właści- } \\
\text { ciel }\end{array}$ \\
\hline $\begin{array}{l}\text { Przypadkowy (brak stosowania } \\
\text { metodyki) }\end{array}$ & $27,8 \%$ & $14,7 \%$ & $13,8 \%$ & $35,3 \%$ \\
\hline $\begin{array}{l}\text { Częściowo metodyczny (są wykorzystane } \\
\text { elementy metodyki zarządzania } \\
\text { projektami) }\end{array}$ & $30,1 \%$ & $48,8 \%$ & $20,7 \%$ & $52,9 \%$ \\
\hline $\begin{array}{l}\text { Metodyczny, ale zróżnicowany } \\
\text { (poszczególne projekty są zarządzane } \\
\text { w sposób uporządkowany, zgodny } \\
\text { z metodyką, jednakże stosowane } \\
\text { metodyki różnią się dla poszczególnych } \\
\text { projektów) }\end{array}$ & $29,5 \%$ & $18,6 \%$ & $44,8 \%$ & $5,9 \%$ \\
\hline $\begin{array}{l}\text { Kompleksowy (wspólna metodyka dla } \\
\text { większości realizowanych projektów) }\end{array}$ & $12,5 \%$ & $17,8 \%$ & $20,7 \%$ & $5,9 \%$ \\
\hline
\end{tabular}

Źródto: opracowanie własne.

Tabela 3. Sposoby zarządzania projektami w organizacji ze względu na sektor działania organizacji

\begin{tabular}{|l|c|c|c|c|}
\hline \multicolumn{1}{|c|}{ Sposoby zarządzania projektami w organizacji } & Usługi & Produkcja & Handel & IT \\
\hline Przypadkowy (brak stosowania metodyki) & $32,4 \%$ & $20,0 \%$ & $36,4 \%$ & $1,4 \%$ \\
\hline $\begin{array}{l}\text { Częściowo metodyczny (są wykorzystane elementy } \\
\text { metodyki zarządzania projektami) }\end{array}$ & $26,8 \%$ & $42,5 \%$ & $31,8 \%$ & $40,6 \%$ \\
\hline $\begin{array}{l}\text { Metodyczny, ale zróżnicowany (poszczególne projekty } \\
\text { są zarządzane w sposób uporządkowany, zgodny } \\
\text { z metodyką, jednakże stosowane metodyki różnią się } \\
\text { dla poszzzególnych projektów) }\end{array}$ & $23,2 \%$ & $25,0 \%$ & $20,5 \%$ & $30,4 \%$ \\
\hline $\begin{array}{l}\text { Kompleksowy (wspólna metodyka dla większości } \\
\text { realizowanych projektów) }\end{array}$ & $17,6 \%$ & $12,5 \%$ & $11,4 \%$ & $27,5 \%$ \\
\hline
\end{tabular}

Źródto: opracowanie własne.

Drugi obszar postępowania badawczego dotyczył wskazania przykładów metodyk zarządzania projektami, wykorzystywanych w organizacjach zatrudniających ankietowanych. Wyniki zaprezentowane na rysunku 3 wskazują na wyraźną 
dominację trzech metodyk - PMBoK (36,4\% wskazań), Agile (36\% wskazań) oraz PRINCE2 (35\% wskazań).

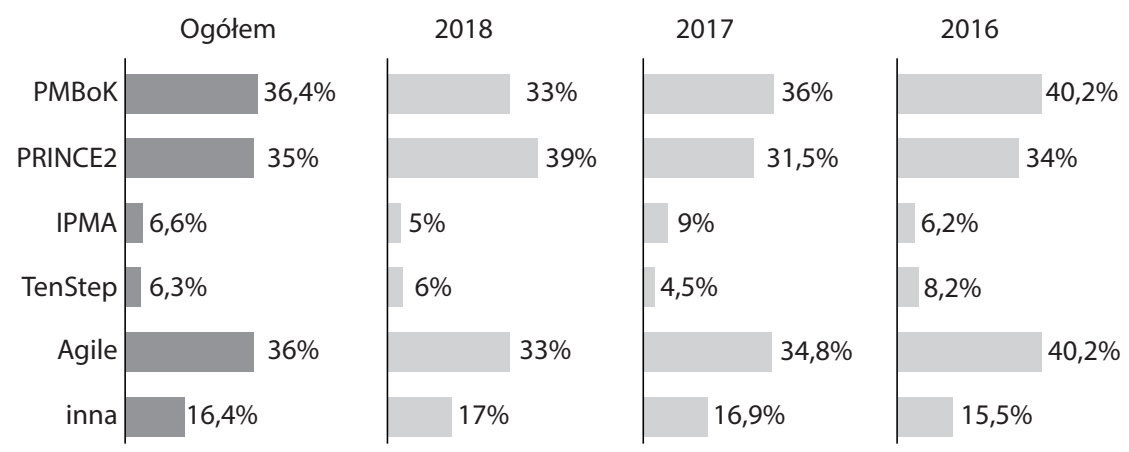

Rysunek 3. Rodzaje metodyk stosowanych w organizacji

Źródło: opracowanie własne.

W badanym obszarze zaobserwować można różnice ze względu na sektor działalności badanych organizacji (por. tabela 4). W sektorze IT odnotowano jednoznaczną supremację (81,2\% wskazań) metodyk zwinnych, tradycyjnie kojarzonych z tym sektorem gospodarki. Najpopularniejszą metodyką zarządzania projektami w przedsiębiorstwach produkcyjnych oraz handlowych okazała się metodyka PMBoK (odpowiednio 48,4\% oraz 34,6\% wskazań), natomiast jako najczęściej stosowaną metodykę zarządzania projektami w przedsiębiorstwach usługowych wskazano PRINCE2 (41,3\% wskazań).

Tabela 4. Rodzaje metodyk stosowanych w organizacji

ze względu na sektor działania organizacji

\begin{tabular}{|l|r|r|r|r|}
\hline \multicolumn{1}{|c|}{ Metodyka } & Ustugi & Produkcja & Handel & \multicolumn{1}{c|}{ IT } \\
\hline PMBoK & $33,7 \%$ & $48,4 \%$ & $34,6 \%$ & $26,1 \%$ \\
\hline PRINCE2 & $41,3 \%$ & $33,0 \%$ & $30,8 \%$ & $29,0 \%$ \\
\hline IPMA & $4,3 \%$ & $2,2 \%$ & $11,5 \%$ & $11,6 \%$ \\
\hline TenStep & $7,6 \%$ & $9,9 \%$ & $7,7 \%$ & $0,0 \%$ \\
\hline Agile (np. Scrum) & $30,4 \%$ & $15,4 \%$ & $11,5 \%$ & $81,2 \%$ \\
\hline Inna metodyka & $14,1 \%$ & $27,5 \%$ & $19,2 \%$ & $5,8 \%$ \\
\hline
\end{tabular}

Źródło: opracowanie własne.

Kolejny obszar postępowania badawczego dotyczył oceny przydatności metodyk zarządzania projektami w organizacji (rysunek 4). Uzyskane wyniki pozwalają na ocenę przydatności (wartości średnie) wybranych metodyk zarządzania projektami w organizacji. Najwyższe oceny średnie odnotowano dla metodyk Agile (śr $=3,34$ ) oraz PMBoK (śr = 3,08), co z jednej strony potwierdza rosnącą 
popularność metodyk zwinnych, obserwowaną na przestrzeni ostatnich 15-20 lat oraz ciągle wysoką ocenę tradycyjnych metodyk kaskadowych (np. PMBoK). Należy jednak zwrócić uwagę na relatywnie stabilną ocenę przydatności metodyk zwinnych w latach 2016-2018 oraz malejącą ocenę przydatności metodyk tradycyjnych - zwłaszcza PMBoK (od śr = 3,49 w 2016 roku do śr = 3,10 w 2018 roku) oraz TenStep (od śr = 3,16 w 2016 roku do 2,91 w 2018 roku). Ocena przydatności pozostałych metodyk zarządzania projektami (PRINCE2 oraz IPMA) jest względnie stabilna (śr $\approx 3,00)$.

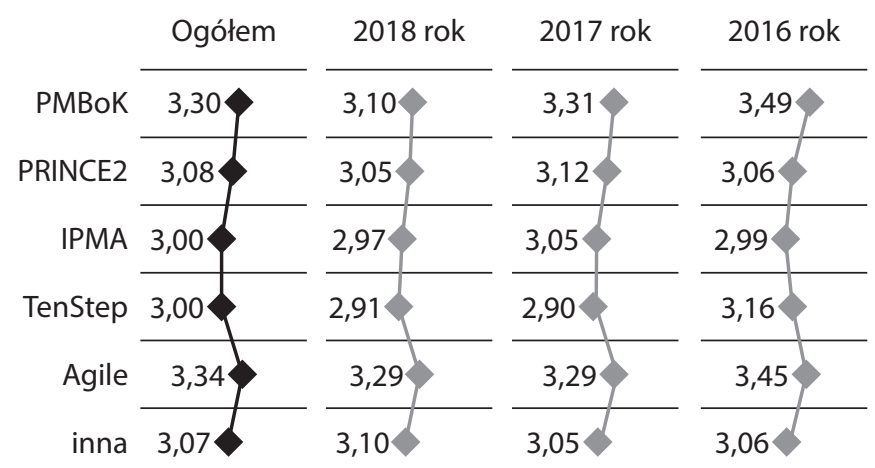

Rysunek 4. Ocena przydatności metodyk zarządzania projektami w organizacji

Źródto: opracowanie własne.

Wyniki przeprowadzonych badań wskazują, że ocena przydatności metodyk zarządzania projektami w organizacji jest różna ze względu na staż pracy w projektach (tabela 5).

Tabela 5. Ocena przydatności metodyk zarządzania projektami w organizacji ze względu na staż pracy w projektach

\begin{tabular}{|l|c|c|c|}
\hline \multicolumn{1}{|c|}{ Metodyka } & Do roku & Powyżej roku do 5 lat & Powyżej 5 lat \\
\hline PMBoK & 3,13 & 3,44 & 3,19 \\
\hline PRINCE2 & 2,90 & 3,21 & 2,97 \\
\hline IPMA & 3,05 & 3,04 & 2,93 \\
\hline TenStep & 2,98 & 2,98 & 3,03 \\
\hline Agile (np. SCRUM) & 3,32 & 3,24 & 3,50 \\
\hline Inna & 3,07 & 3,06 & 3,08 \\
\hline
\end{tabular}

Źródto: opracowanie własne.

Wyniki zaprezentowane w tabeli 5 wskazują na prawidłowość, zgodnie z którą oceny przydatności (wartości średnie) tradycyjnych metodyk zarządzania projektami są najwyższe w przypadku osób o stażu pracy w projektach od roku do 5 lat. 
Mniejsze znaczenie tych metodyk w przypadku respondentów z krótkim stażem pracy w projektach (do roku) wynikać może z konieczności zdobycia doświadczenia zawodowego, z kolei malejąca ich popularność w grupie najbardziej doświadczonych respondentów wskazywać może na występowanie refleksji związanej z pragmatyką stosowania tych metodyk z jednej strony oraz poszukiwaniem usprawnień organizacyjnych z drugiej. Ocena przydatności metodyki TenStep jest relatywnie stabilna, natomiast wraz ze stażem pracy rośnie znaczenie metodyk zwinnych.

Uzyskane wyniki wykazały, że ocena przydatności metodyk zarządzania projektami w organizacji jest różna ze względu na funkcje pełnione przez respondentów w organizacji (tabela 6).

Tabela 6. Ocena przydatności metodyk zarządzania projektami w organizacji ze względu na petnioną funkcję w organizacji

\begin{tabular}{|l|c|c|c|c|}
\hline \multicolumn{1}{|c|}{ Metodyka } & $\begin{array}{c}\text { Cztonek zespołu } \\
\text { projektowego }\end{array}$ & Project manager & $\begin{array}{c}\text { Menedżer } \\
\text { portfela }\end{array}$ & Wtaściciel \\
\hline PMBoK & 3,41 & 3,24 & 3,14 & 2,88 \\
\hline PRINCE2 & 3,15 & 2,97 & 3,10 & 3,18 \\
\hline IPMA & 3,02 & 3,00 & 2,83 & 3,00 \\
\hline TenStep & 3,08 & 2,85 & 2,93 & 3,24 \\
\hline Agile (np. SCRUM) & 3,24 & 3,55 & 3,21 & 3,53 \\
\hline Inna & 3,04 & 3,09 & 3,07 & 3,24 \\
\hline
\end{tabular}

Źródło: opracowanie własne.

Uzyskane wyniki pozwalają na ocenę znaczenia wyodrębnionych metodyk zarządzania projektami z perspektywy funkcji pełnionych w projektach. Najstarsza z metodyk - PMBoK - jest najbardziej utylitarna w grupach członków zespołów projektowych (śr $=3,41$ ) oraz project managerów (śr $=3,24)$, a jej przydatność jest najmniejsza z perspektywy właścicieli organizacji (śr $=2,88$ ). Kolejna z metodyk tradycyjnych - PRINCE2 - jest najbardziej ceniona w grupach właścicieli organizacji (śr $=3,18)$ oraz członków zespołów projektowych (śr = 315). Co ciekawe, jej utylitarność na najniższym poziomie oceniona została z perspektywy project managerów (śr $=2,97$ ). Przydatność metodyki IPMA w organizacji jest oceniana podobnie w grupach członków zespołów projektowych (śr $=3,02$ ), project managerów (śr $=3,00$ ) oraz właścicieli organizacji (śr $=3,00)$. Według respondentów jej znaczenie maleje dla menedżerów portfela projektów (śr $=2,83)$. Znaczenie metodyki TenStep jest najwyższe w grupie właścicieli (śr = 3,24), następnie członków zespołów projektowych (śr = 3,08), menedżerów portfela projektów ('śr $=2,93)$, natomiast najniższe dla project managerów (śr $=2,85$ ). Z kolei ocena przydatności metodyk zwinnych jest wysoka dla każdej z wyszczególnionych funkcji pełnionych w organizacji - najwyższa dla project managerów (śr $=3,55)$, następnie dla właścicieli organizacji (śr = 3,53), członków zespołów projektowych (śr = 3,24) oraz 
menedżerów portfela projektów (śr $=3,21$ ). Wysokie znaczenie metodyk zwinnych wynikać może ze specyfiki projektów realizowanych przy ich zastosowaniu (najczęściej są to projekty informatyczne), niewielkich grup projektowych, gwarantujących elastyczność funkcjonowania oraz bezpośredniej partycypacji właścicieli organizacji w projektach. W tym kontekście nie jest zaskoczeniem najniższa ocena metodyk zwinnych w przypadku menedżerów portfeli projektów, których funkcja w organizacji wymaga korzystania $\mathrm{z}$ innych instrumentów, metod lub metodyk zarządzania projektami.

Ocena przydatności metodyk zarządzania projektami w organizacji jest również odmienna ze względu na sektor funkcjonowania organizacji (tabela 7).

Tabela 7. Ocena przydatności metodyk zarządzania projektami w organizacji ze względu na sektor działania organizacji

\begin{tabular}{|l|c|c|c|c|}
\hline \multicolumn{1}{|c|}{ Metodyka } & Usługi & Produkcja & Handel & IT \\
\hline PMI & 3,46 & 3,28 & 3,25 & 3,03 \\
\hline PRINCE2 & 3,21 & 3,18 & 3,07 & 2,52 \\
\hline IPMA & 3,07 & 3,06 & 3,07 & 2,67 \\
\hline TEN STEP & 3,11 & 3,03 & 3,07 & 2,67 \\
\hline Agile (np. SCRUM) & 3,25 & 2,99 & 3,27 & 4,22 \\
\hline Inna & 3,06 & 3,17 & 3,02 & 2,97 \\
\hline
\end{tabular}

Źródto: opracowanie własne.

W sektorze usług najbardziej przydatną metodyką zarządzania projektami jest PMI (śr = 3,46), w sektorze produkcyjnym również metodyka PMI (śr = 3,28), w sektorze handlowym metodyki PMI (śr = 3,25) oraz AGILE (śr = 3,27), natomiast w sektorze IT zdecydowanie metodyki zwinne (śr $=4,22)$.

\section{Zakończenie}

Najważniejsze wnioski z przeprowadzonych badań empirycznych są następujące:

- w organizacjach zatrudniających ankietowanych najczęściej stosowany jest częściowo metodyczny sposób zarządzania projektami, przy czym sektor IT wskazano jako ten, w którym wykorzystanie metodyk zarządzania projektami w organizacji występuje najczęściej, a ponadto rosnący staż pracy w projektach wiąże się ze stosowaniem bardziej zaawansowanych sposobów zarządzania projektami;

- deklaracje respondentów wskazują, że trzema najpopularniejszymi metodykami zarządzania projektami w zatrudniających ich organizacjach są kolejno PMBoK, Agile oraz PRINCE2, przy czym można zaobserwować dominację wybranych metodyk dla poszczególnych sektorów, tj. metodyk zwinnych 
w sektorze IT, PMBoK w sektorach produkcyjnym i handlowym, wreszcie PRINCR2 w sektorze usług;

- respondenci stosunkowo wysoko ocenili przydatność stosowanych metodyk zarządzania projektami, przy czym najwyższe oceny średnie odnotowano dla metodyk Agile oraz PMBoK.

Należy podkreślić istotne ograniczenie szerszej interpretacji przedstawionych wyników badań ze względu na brak reprezentatywności wykorzystanej próby badawczej. Wśród możliwych do podjęcia kierunków dalszych badań za szczególnie interesujące uznać należy analizę procesu wyboru metodyki zarządzania projektami w organizacjach oraz analizę relacji zachodzących między cechami - zarówno organizacji, jak i uczestników projektów - a skutecznością zarządzania projektami różnych typów.

\section{Bibliografia}

A Guide to the Project Management Body of Knowledge, Fifth edition, Project Management Institute, Inc., Management Training and Development Centre, Warszawa 2013.

Brzozowski M., Bartkowiak P., Kompetencje uczestników projektu w świetle badań empirycznych, „Przegląd Organizacji” 2019, nr 8, s. 41-49.

Brzozowski M., Kopczyński T., Zarzq̨dzanie projektami i zmianami w przedsiębiorstwie, Advertiva, Poznań 2011.

Bukłaha E., Juchniewicz M., Kluczowe wyzwania i bariery oraz trendy w zarzq̨dzaniu projektami z punktu widzenia projektów realizowanych w Polsce, „Przegląd Organizacji” 2019, nr 3, s. 14-20.

Głodziński E., Efektywność w zarzq̨dzaniu projektami, Polskie Wydawnictwo Ekonomiczne, Warszawa 2017.

IPMA, Wytyczne Kompetencji Indywidualnych w Zarzadzaniu Projektami, Programami i Portfelami. IPMA Individual Competence Baseline ${ }^{\circledast}$ (IPMA ICB). Wersja 4.0, 2015.

Lichtarski J.M., Wąsowicz M., Zarządzanie projektami - stan i perspektywy rozwoju subdyscypliny, [w:] K. Jędralska, W. Dyduch (red.), Nauki o zarzq̨dzaniu: dokonania, trendy, wyzwania, Wydawnictwo Uniwersytetu Ekonomicznego w Katowicach, Katowice 2017, s. 124-136.

Nogalski B., Szpitter A., Jabłoński M., Zarzqdzanie projektami w kształtowaniu elastycznych modeli biznesu operatorów systemu dystrybucyjnego, Wydawnictwo Uniwersytetu Gdańskiego, Gdańsk 2016.

OGC, Managing Successful Projects with PRINCE2, The Stationery Office, London 2009.

Schwaber K., Sutherland J., Scrum Guide. Przewodnik po Scrumie: reguty gry, Scrum.Org and Scrumlnc., 2013.

Szpitter A., Metodyki zarządzania projektami stosowane przez project managerów u operatorów systemu dystrybucyjnego w Polsce. Studium empiryczne, Wydawnictwo Uniwersytetu Gdańskiego, Gdańsk 2018.

TenStep Project Management Process v13.0, June 2014.

Trocki M., Podejścia badawcze w zarzq̨dzaniu projektami - geneza i ewolucja, „Przegląd Organizacji" 2019, nr 3, s. 3-9.

Trocki M. (red.), Metodyki i standardy zarzq̨dzania projektami, Polskie Wydawnictwo Ekonomiczne, Warszawa 2017. 


\section{Streszczenie}

Głównym celem artykułu jest zbadanie, na podstawie przeprowadzonych badań empirycznych, postrzeganego sposobu zarządzania projektami w organizacjach, jak również określenie częstotliwości stosowania wybranych metodyk zarządzania projektami wraz z oceną ich przydatności. W pierwszej części artykułu przedstawiono - zidentyfikowane na podstawie studiów literaturowych - rodzaje i przykłady metodyk zarządzania projektami, a w drugiej części wyniki badań empirycznych przeprowadzonych z wykorzystaniem kwestionariusza ankiety wśród uczestników projektów realizowanych w organizacjach różnego typu. Badanie wykazało, że w organizacjach zatrudniających ankietowanych najczęściej stosowany jest częściowo metodyczny sposób zarządzania projektami, natomiast najpopularniejszymi metodykami zarządzania projektami były PMBoK, Agile oraz PRINCE2, przy czym respondenci wysoko ocenili przydatność stosowanych metodyk zarządzania projektami.

Słowa kluczowe: zarządzanie projektami, metodyka zarządzania projektami, kierownik projektu

\section{The use of project management methodologies according to empirical research}

\section{Abstract}

The main purpose of the chapter is to examine, on the basis of empirical research, the perceived manner of project management in organizations, as well as to determine the frequency of application of selected project management methodologies along with an assessment of their usefulness. The first part of the article presents - identified on the basis of literature studies - types and examples of project management methodologies, and in the second - the results of empirical research conducted using a questionnaire among participants of projects implemented in various types of organizations. The study showed that in organizations employing respondents, the methodical manner of project management is most often used, while the most popular project management methodologies were PMBoK, Agile and PRINCE2, and respondents highly rated the usefulness of project management methodologies.

Keywords: project management, project management methodology, project manager 